\title{
Effect of dietary energy levels on growth performance, blood parameter and intestinal morphology of Pekin ducks in low ambient temperature
}

\author{
Chan Ho Kim, Hwan Ku Kang* and Hyun Soo Kim \\ Poultry Research Institute, National Institute of Animal Science, RDA, Pyeongchang 25342, Korea
}

\begin{abstract}
This study was carried out to investigate the effects of dietary energy levels on growth performance, blood parameter, and intestinal morphology of Pekin ducks in low temperature. A total of 500, 21-d-old Pekin ducks (initial BW =1,089 $\pm 5.21 \mathrm{~g}$ ) were evenly assigned to five dietary treatments $(2,950,3,000,3,050,3,100$, or 3,150 kcal AME/kg, calculated on an as-is basis) with four replicates (pens) for each treatment ( 25 ducks per pen). During the experiment, hens were provided with feed and water ad libitum. Overall, increasing dietary energy levels corresponded to an increase of final body weight and body weight gain (linear, $p<0.01$ ). Feed intake decreased (linear, $p<0.01$ ) and feed conversion ratio increased (linear, $p$ $<0.01)$ with increasing levels of energy. There were no significant differences $(p<0.05)$ in the level of leukocytes between groups. However, heterophils decreased (quadratic, $p<0.05$ ) and lymphocytes increased (linear, $p<0.01$ ) as inclusion of dietary energy levels increased. The $\mathrm{H} / \mathrm{L}$ ratio increased (linear, $p<0.01$ ) with increasing dietary energy levels while serum corticosterone levels decreased at overall experimental periods. Triglycerides increased (linear and quadratic, $p<0.05$ ) with increasing dietary energy levels. There were no significant changes in villus height or crypt depth of the jejunum at overall experimental. In conclusion, increasing concentrations of dietary energy levels up to 2,950-3,150 kcal/kg in diet. Additionally, $3,150 \mathrm{kcal} / \mathrm{kg}$ dietary energy had been revealed more beneficial and could be practiced as protective management for the Pekin ducks reared under low ambient temperature $\left(8^{\circ} \mathrm{C}\right.$ to $\left.10^{\circ} \mathrm{C}\right)$.
\end{abstract}

Keywords: Corticosterone, $\mathrm{H} / \mathrm{L}$ ratio, Metabolizable energy, Low ambient temperature, Pekin duck

\section{Background}

Poultry producers face serious losses when chickens are exposed to adverse environmental conditions such as the presence of infectious agents, extreme temperature (heat or cold), poor air quality, environmental contaminants, and other conditions such as light and diet also may influence the health status of poultry [1]. Low ambient temperature is one of the most significant environmental stressors and can significantly affect the health and welfare of poultry [2]. Low ambient temperature occurs when the surrounding temperature falls below $8^{\circ} \mathrm{C}$ to $12^{\circ} \mathrm{C}[3,4]$. The body may not be able to warm itself, and serious cold-related illnesses, permanent tissue damage, and death may occur as a result of low ambient temperature [4]. Low ambient temperatures increase feed intake, but decrease the growth potential of laying hens and Japanese quails [5-8]. Similar to cold stress, serum corticosterone, blood 
glucose and cholesterol levels increased significantly [9,10]. Insulin and corticosterone are well known to be temperature-sensitive and important hormones that control nutrient metabolism [11]. Voluntary feed intake and the consequent productivity of animals depends largely on various animal and environmental factors, and feed energy density is considered as the most important factor that influences voluntary feed intake [12]. Moreover, from an economic standpoint feed represents the largest portion of total animal production costs; therefore, the accurate estimation of feed energy values is crucial for realizing optimal animal production [12]. Animals are known to adjust the daily feed intake containing various concentrations of energy to maintain a constant daily energy intake [13-14]. Current metabolizing energy dietary requirements for ducks are estimated to be $3,000 \mathrm{kcal}$ AME/kg [15]. One of the limitations of elucidating the relationship between low ambient temperature and duck growth performance is how to express dietary energy concentrations. The objective of this study, therefore, was to investigate whether level of dietary energy would counter the positive effects of cold stress on growth performance, plasma corticosterone, and intestinal morphology.

\section{Methods}

The protocol for this experiment was reviewed and approved by the Institutional Animal Care and Welfare Committee of the National Institute of Animal Science, Rural Development Administration, Korea.

\section{Birds and experimental design}

A total of 500,21-day-old Pekin Ducks (initial BW [body weight] $=1,089 \pm 5.21 \mathrm{~g}$ ) were evenly assigned to five dietary treatments $(2,950,3,000,3,050,3,100$, or $3,100 \mathrm{kcal} \mathrm{AME} / \mathrm{kg})$. There were four replicates of each treatment, each consisting of 25 ducks in a pen. All birds were fed a common starter diet from 0 to $20 \mathrm{~d}$ of age and an experimental diet during the experimental period from 21 to $42 \mathrm{~d}$. A commercial type basal diet was formulated to meet or exceed the nutrient recommendations of the National Research Council [15] for ducks (Table 1). Till the end of this experiment, the average ambient temperature and relative humidity inside the house were recorded $8 \pm 2.1^{\circ} \mathrm{C}$ and $62.35 \pm 2.7 \%$. A 24-h light schedule was used throughout the entire experiment. Diet samples were analyzed for dry matter (DM, Method 930.15), ash (Method 942.05), ether extract (EE, Method 2003.03), and crude protein (CP, Method 990.03) [16]. Diet samples were also analyzed for apparent metabolizable energy (AME) using bomb calorimetry (Model 6400, Parr Instruments Co., Moline, IL, USA) with benzoic acid as the standard for calibration.

\section{Growth performance}

Body weight gain (g; BWG) and feed intake (g; FI) were measured weekly. The feed conversion ratio (FCR) was calculated as the ratio of BWG to FI. BWG, FI, and FCR were corrected for dead birds.

\section{Blood samples}

Blood samples were collected from wing vein of randomly selected eight birds in each treatment using EDTA-treated BD Vacutain$\mathrm{er}^{\circledR}$ tubes and non EDTA-treated BD Vacutainer ${ }^{\circledR}$ tubes (Becton Dickinson, Franklin Lakes, NJ, USA). The whole blood samples were kept on ice and used for immediate analysis of hematology. Leukocytes (white blood cells, heterophils, lymphocytes, monocytes, eosinophils, basophils) were analyzed using Hemavet ${ }^{\circledR}$ Multispecies Hematology System (Drew Scientific Inc., Oxford, CT, USA). The $\mathrm{H} / \mathrm{L}$ ratios were determined by dividing the number of heterophils by that of lymphocytes. Serum samples were obtained by centrifuging the samples for $20 \mathrm{~min}$ at $25,000 \times \mathrm{g}$ and $4{ }^{\circ} \mathrm{C}$ and were stored at $-15^{\circ} \mathrm{C}$. Total cholesterol, triglyceride, asperate aminotransferase (AST), alanine aminotransferase (ALT), and calcium in the serum were quantified using an $\mathrm{ADVIA}^{\circledR} 1650$ chemistry system (Bayer Diagnostic, Puteaux, France).

\section{Serum corticosterone}

Blood samples (Serum corticosterone) were collected from wing vein of randomly selected eight birds in each treatment using Vacutainer ${ }^{\circledR}$ tubes (Becton Dickinson, Franklin Lakes, NJ, USA) before morning feeding on $\mathrm{d} 0,2,4,7,14$, and 21 of the experiment. Serum corticosterone was determined by enzyme-linked immunoassay (EIA). The EIA kits (Corticosterone EIA Kit, Assay Designs, Inc., Ann Arbor, MI, USA) were based on a sheep polyclonal antibody raised against corticosterone. This assay method has been compared directly with radioimmunoassay procedures (RIA), and precision and accuracy of the EIA assay have been shown to exceed that of RIA. The EIA procedure involved pipetting $10 \mu \mathrm{L}$ of each serum sample into an Eppendorf tube ${ }^{\circledR}$ and adding $10 \mu \mathrm{L}$ of steroid inhibitor buffer. The solution was then vortexed and all samples were brought to a 1:40 dilution using Tris buffer solution with sodium azide. An aliquot of each sample (100 $\mu \mathrm{L}$ ) was pipetted into microtiter plate wells (coated with donkey-anti-sheep $\mathrm{IgG}$ ) in duplicate. In addition, $50 \mu \mathrm{L}$ of alkaline phosphatase conjugated with corticosterone and sheep polyclonal antibody was added to each well. After $2 \mathrm{~h}$ of incubation on a shaker $(4,200 \times \mathrm{g})$ at room temperature, plates were washed 3 times in Tris buffer solution containing detergents and sodium azide. A solution of o-nitrophenyl phosphate $(200 \mu \mathrm{L})$ was added to each well and the plate was incubated for another hour (without shaking) at room temperature. The stop the reaction, $50 \mu \mathrm{L}$ of trisodium phosphate solution, was added and absorbance was read spectro- 
Table 1. Composition and nutrient content of experimental diets (as-fed basis)

\begin{tabular}{|c|c|c|c|c|c|}
\hline \multirow[b]{2}{*}{ Ingredients (\%) } & \multicolumn{5}{|c|}{ Dietary ME concentrations (kcal/kg) } \\
\hline & 2,950 & 3,000 & 3,050 & 3,100 & 3,150 \\
\hline Maize & 57.07 & 59.80 & 58.71 & 57.41 & 56.63 \\
\hline Soybean meal & 22.55 & 22.78 & 22.89 & 23.25 & 23.02 \\
\hline Wheat & 10.00 & 8.00 & 8.00 & 8.00 & 8.00 \\
\hline Barley & 6.60 & 5.00 & 5.00 & 5.00 & 5.00 \\
\hline Soybean oil & 0.28 & 0.83 & 1.75 & 2.74 & 3.60 \\
\hline Limestone & 0.90 & 0.90 & 0.90 & 0.90 & 0.90 \\
\hline MDCP & 1.10 & 1.10 & 1.10 & 1.10 & 1.10 \\
\hline HCl-Lysine-78\% & 0.25 & 0.34 & 0.40 & 0.35 & 0.50 \\
\hline Salt & 0.25 & 0.25 & 0.25 & 0.25 & 0.25 \\
\hline Vitamin premix $^{1)}$ & 0.50 & 0.50 & 0.50 & 0.50 & 0.50 \\
\hline Mineral premix ${ }^{2)}$ & 0.50 & 0.50 & 0.50 & 0.50 & 0.50 \\
\hline Total & 100.00 & 100.00 & 100.00 & 100.00 & 100.00 \\
\hline \multicolumn{6}{|l|}{ Calculated composition ${ }^{3)}$} \\
\hline $\mathrm{AME}_{\mathrm{n}}(\mathrm{kcal} / \mathrm{kg})$ & $2,950.0$ & $3,000.0$ & 3,050 & $3,100.0$ & $3,150.0$ \\
\hline Crude protein (\%) & 18.33 & 18.31 & 18.32 & 18.34 & 18.30 \\
\hline Ether extract (\%) & 2.98 & 3.57 & 4.45 & 5.40 & 6.22 \\
\hline Lysine (\%) & 1.08 & 1.15 & 1.20 & 1.16 & 1.27 \\
\hline Met+Cys (\%) & 0.59 & 0.59 & 0.59 & 0.59 & 0.58 \\
\hline Calcium (\%) & 0.62 & 0.62 & 0.62 & 0.62 & 0.62 \\
\hline Available P (\%) & 0.35 & 0.35 & 0.35 & 0.35 & 0.35 \\
\hline \multicolumn{6}{|l|}{ Analyzed composition ${ }^{4)}$} \\
\hline GE (kcal/kg) & $3,650.4$ & $3,662.3$ & $3,702.2$ & $3,780.4$ & $3,810.5$ \\
\hline $\mathrm{DM}(\%)$ & 89.50 & 89.57 & 89.59 & 90.55 & 90.53 \\
\hline Crude protein (\%) & 17.28 & 17.26 & 17.30 & 17.24 & 17.23 \\
\hline Ether extract (\%) & 2.78 & 3.84 & 4.38 & 5.71 & 6.09 \\
\hline Crude ash (\%) & 4.69 & 4.81 & 5.53 & 5.20 & 3.27 \\
\hline Crude fiber (\%) & 2.66 & 2.71 & 2.74 & 2.76 & 2.62 \\
\hline
\end{tabular}

${ }^{1)}$ Provided per kilogram of the complete diet: vitamin $\mathrm{A}$ (vitamin A acetate), 12,500 IU; vitamin $\mathrm{D}_{3}, 2,500 \mathrm{IU}$; vitamin $\mathrm{E}$ (DL-a-tocopheryl acetate), 20 IU; vitamin $\mathrm{K}_{3}, 2$ mg; vitamin $\mathrm{B}_{1}, 2 \mathrm{mg}$; vitamin $\mathrm{B}_{2}, 5 \mathrm{mg}$; vitamin $\mathrm{B}_{6}, 3 \mathrm{mg}$; vitamin $\mathrm{B}_{12}, 18 \mu \mathrm{g}$; calcium pantotenate, $8 \mathrm{mg}$; folic acid, $1 \mathrm{mg}$; biotin $50 \mu \mathrm{g}$; niacin, $24 \mathrm{mg}$.

${ }^{2)}$ Provided per kilogram of the complete diet: $\left.\mathrm{Fe}\left(\mathrm{FeSO}_{4} \cdot 7 \mathrm{H}_{2} \mathrm{O}\right), 40 \mathrm{mg} ; \mathrm{Cu}\left(\mathrm{CuSO}_{4} \cdot \mathrm{H}_{2} \mathrm{O}\right), 8 \mathrm{mg} ; \mathrm{Zn}\left(\mathrm{ZnSO}_{4} \cdot \mathrm{H}_{2} \mathrm{O}\right), 60 \mathrm{mg} ; \mathrm{Mn}^{(\mathrm{MnSO}}{ }_{4} \cdot \mathrm{H}_{2} \mathrm{O}\right) 90 \mathrm{mg} ; \mathrm{Mg}_{(\mathrm{MgO})}$ as $1,500 \mathrm{mg}$.

${ }^{3)}$ Calculated value.

${ }^{4)}$ Analyzed value.

$\mathrm{ME}$, metabolizable energy; MDCP, monodicalcium phosphate; GE, gross energy; DM, dry matter.

photometrically ( $\mu$ Quant ${ }^{\mathrm{TM}}$ Microplate spectrophotometer, BioTek Instruments, Inc., Winooski, VT, USA) at $450 \mathrm{~nm}$. Standard curves and sample concentrations were calculated using $\mathrm{KC}$ junior Software (Bio-Tek Instruments, Inc.).

\section{Intestinal morphology measurements}

On d 7, d 14, and d 21, four birds (one bird per pen) were randomly selected from each treatment. Carcasses of the sacrificed birds were immediately opened and the entire intestine was removed aseptically. A 2-cm sample of the jejunum (midpoint between the bile duct entry and Meckel's diverticulum) was collected. Each of these intestinal segments was flushed with physiological saline solution $(0.9 \% \mathrm{NaCl})$ to remove intestinal contents, fixed in $10 \%$ neutral buffered formalin, and kept at $4{ }^{\circ} \mathrm{C}$ prior to the microscopic assessment of intestinal morphology [17]. Formalin-fixed intestinal tissues were processed, embedded in paraffin wax, sectioned at 3 $\mu \mathrm{m}$, and stained using the hematoxylin-eosin method. Histological sections were examined with a Nikon phase contrast microscope coupled with a Microcomp integrated digital imaging analysis system (Nikon Eclipse 80i, Nikon Co., Tokyo, Japan). Images were viewed using a 4x Eplan objective lens (40x) to measure morphometric parameters of intestinal architecture.

For this purpose, three favorably oriented sections cut perpendicularly from the villus enterocytes to the muscularis mucosa were 
selected from each animal, and two measurements were made of these sections. Villus height was estimated by measuring the vertical distance from the villus tip to the villus-crypt junction level for 10 villi per section. Crypt depth (the vertical distance from the villus-crypt junction to the lower limit of the crypt) was estimated for 10 corresponding crypts per section.

\section{Statistical analysis}

Differences in variables between ducks fed increasing amounts of AME were analyzed by ANOVA for completely randomized designs using the Proc MIXED procedure of SAS (SAS Institute, Inc., Cary, NC, USA). The UNIVARIATE procedure of SAS was used to identify outliers but none was found. The experimental unit for all data was the replicate, and dietary treatment was a fixed effect in the models. The LSMEANS procedure was used to calculate mean values. An orthogonal polynomial contrast test was performed to determine linear and quadratic effects of increasing AME concentrations in the diets. Significance and tendency for statistical tests were set at $p<0.05$ and $0.05 \leq p \leq 0.10$, respectively.

\section{Results}

Overall, increasing inclusion of energy in the diets increased final body weight and body weight gain (linear, $p<0.01$ ). Body weight gain was 2,182, 2,295, 2,362, 2,395, and 2,434 $\mathrm{g}$ for the respective increasing dietary energy levels from 2,950 to $3,150 \mathrm{kcal} / \mathrm{kg}$ hens, and these differences were statistically significant. Further, body weight of the $3,000,3,050,3,100$, and $3,150 \mathrm{kcal} / \mathrm{kg}$ groups compared to the $2,950 \mathrm{kcal} / \mathrm{kg}$ group increased by $5.2 \%, 8.2 \%, 9.7 \%$, and $11.5 \%$, respectively. Correspondingly, feed intake decreased (linear, $p<0.01$ ) with increasing inclusion level of dietary energy, and the FCR improved (linear, $p<0.01$ ). The FCR of the other groups improved by $6.6 \%, 11.8 \%, 13.3 \%$, and $15.1 \%$, respectively, compared to the $2,950 \mathrm{kcal} / \mathrm{kg}$ group (Table 2). There were no significant differences in the level of leukocytes between different dietary groups (Table 3). Heterophils decreased (quadratic, $p<0.05$ ) and lymphocytes increased (linear, $p<0.01$ ) with increasing inclusion of energy in the diets. The $\mathrm{H} / \mathrm{L}$ ratio also increased (linear, $p<0.01$ ) as dietary energy was increased, and the mean $\mathrm{H} / \mathrm{L}$ ratio was $0.99,0.82,0.71$,

Table 2. Growth performance of exposed low ambient temperature as affected by different AME concentration in diets

\begin{tabular}{|c|c|c|c|c|c|c|c|c|}
\hline \multirow{2}{*}{ Items } & \multicolumn{5}{|c|}{ Dietary ME concentrations (kcal/kg) } & \multirow{2}{*}{ SEM $^{1)}$} & \multicolumn{2}{|c|}{$p$-value } \\
\hline & 2,950 & 3,000 & 3,050 & 3,100 & 3,150 & & Linear & Quadratic \\
\hline Initial BW (g/bird) & $1,089.0$ & $1,089.5$ & $1,089.3$ & $1,089.0$ & $1,089.9$ & & & \\
\hline Final BW (g/bird) & $3,271.2^{c}$ & $3,384.2^{c}$ & $3,451.2^{b}$ & $3,483.4^{\mathrm{ab}}$ & $3,523.4^{\mathrm{a}}$ & 68.57 & 0.008 & 0.492 \\
\hline BW gain (g/bird) & $2,182.2^{c}$ & $2,294.7^{c}$ & $2,361.9^{b}$ & $2,394.6^{\mathrm{ab}}$ & $2,433.5^{\mathrm{a}}$ & 68.85 & 0.009 & 0.491 \\
\hline Feed intake (g/bird) & $5,890.3^{\mathrm{a}}$ & $5,781.7^{\mathrm{ab}}$ & $5,623.1^{\text {bc }}$ & $5,609.0^{\text {bc }}$ & $5,585.6^{c}$ & 62.16 & $<0.001$ & 0.202 \\
\hline Feed conversion ratio & $2.71^{\mathrm{a}}$ & $2.53^{\mathrm{ab}}$ & $2.39^{\mathrm{bc}}$ & $2.35^{\mathrm{bc}}$ & $2.30^{\mathrm{c}}$ & 0.080 & $<0.001$ & 0.268 \\
\hline
\end{tabular}

Data are least squares means of 4 observations per treatment.

${ }^{1)}$ Pooled error of mean.

${ }^{a-c}$ Means with the different superscripts differ significantly $(p<0.05)$.

AME, apparent metabolizable energy.

Table 3. Blood parameter of exposed low ambient temperature as affected by different AME concentration in diets

\begin{tabular}{|c|c|c|c|c|c|c|c|c|}
\hline \multirow{2}{*}{ Items } & \multicolumn{5}{|c|}{ Dietary ME concentrations (kcal/kg) } & \multirow{2}{*}{ SEM $^{1)}$} & \multicolumn{2}{|c|}{$p$-value } \\
\hline & 2,950 & 3,000 & 3,050 & 3,100 & 3,150 & & Linear & Quadratic \\
\hline \multicolumn{9}{|l|}{ Leukocyte } \\
\hline White blood cells $(\mathrm{K} / \mu \mathrm{L})$ & 26.06 & 23.39 & 22.45 & 27.77 & 26.84 & 1.54 & 0.245 & 0.112 \\
\hline Heterophils $(\mathrm{K} / \mu \mathrm{L})$ & 11.01 & 8.87 & 7.62 & 9.99 & 9.24 & 0.74 & 0.316 & 0.038 \\
\hline 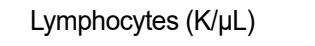 & 11.15 & 10.86 & 10.70 & 12.55 & 12.99 & 0.63 & 0.011 & 0.161 \\
\hline $\mathrm{HE} / \mathrm{LY}^{2)}$ & $0.99^{a}$ & $0.82^{\mathrm{ab}}$ & $0.71^{\mathrm{b}}$ & $0.77^{\mathrm{b}}$ & $0.72^{b}$ & 0.06 & $<0.001$ & 0.112 \\
\hline Monocyte $(\mathrm{K} / \mu \mathrm{L})$ & 2.37 & 2.26 & 2.07 & 2.76 & 2.52 & 0.18 & 0.172 & 0.375 \\
\hline Eosinophils $(\mathrm{K} / \mu \mathrm{L})$ & 1.83 & 1.77 & 1.42 & 1.73 & 1.99 & 0.15 & 0.578 & 0.211 \\
\hline Basophils $(\mathrm{K} / \mu \mathrm{L})$ & 0.85 & 0.82 & 0.66 & 0.74 & 0.68 & 0.09 & 0.589 & 0.132 \\
\hline
\end{tabular}

Data are least squares means of 8 observations per treatment.

${ }^{1)}$ Pooled error of mean.

${ }^{2)} \mathrm{HE} / \mathrm{LY}$, stress index.

${ }^{a, b}$ Means with the different superscripts differ significantly $(p<0.05)$.

AME, apparent metabolizable energy. 


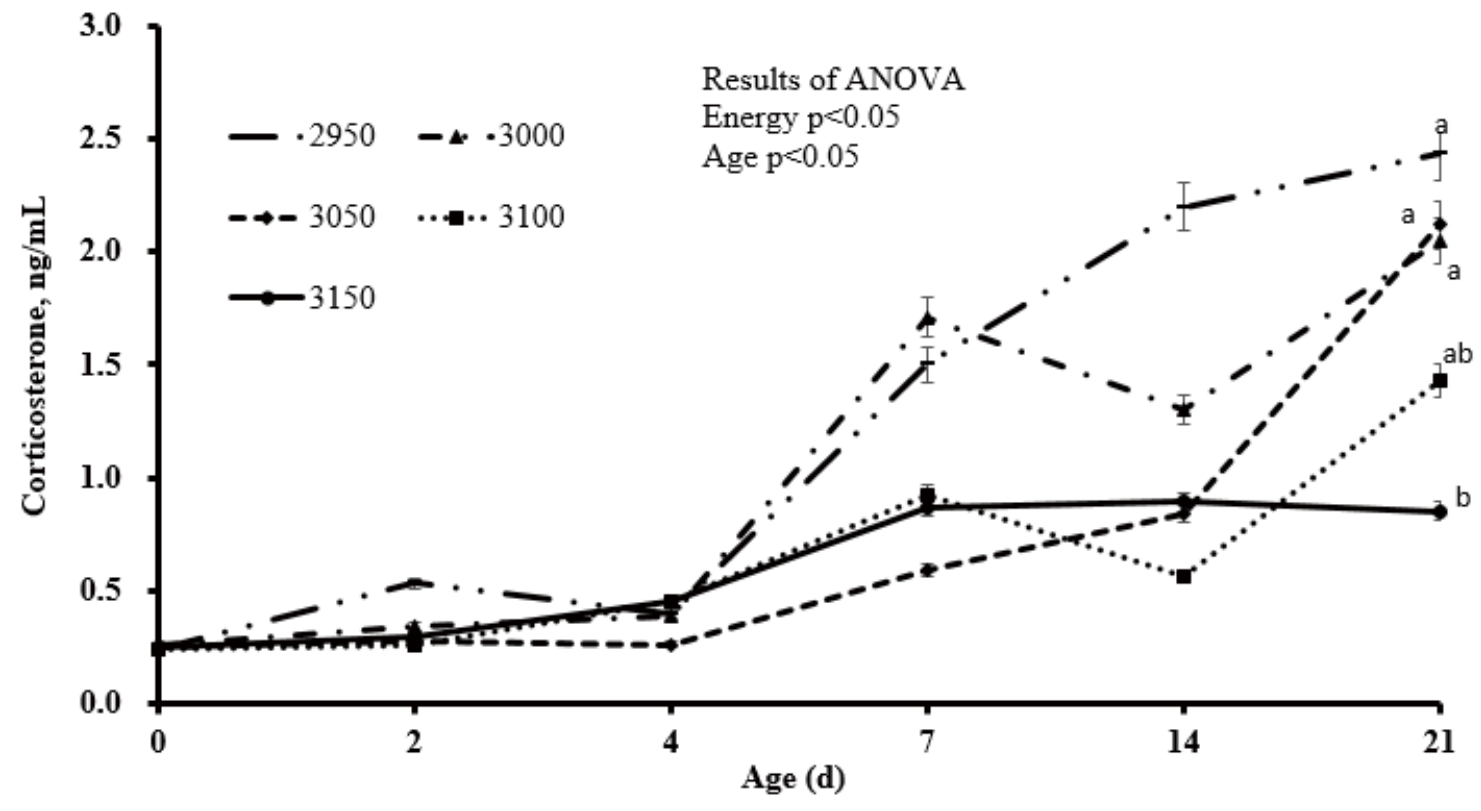

Fig. 1. Serum corticosterone of exposed low ambient temperature as affected by different AME (apparent metabolizable energy) concentration in diets. Data are least squares means of 8 observations per treatment.

0.77 , and 0.72 for the 2,950 to $3,150 \mathrm{kcal}$ AME $/ \mathrm{kg}$ groups, respectively. When compared to the $2,950 \mathrm{kcal} \mathrm{ME} / \mathrm{kg}$ treatment, the $\mathrm{H} /$ $\mathrm{L}$ ratio of the other groups improved by $17.7 \%, 28.8 \%, 22.2 \%$, and $27.3 \%$, respectively. As expected, corticosterone values measured in the serum increased from 0 to $21 \mathrm{~d}$, regardless of dietary treatments (Fig. 1). Increasing inclusion level of dietary energy corresponded to decreases (linear) in corticosterone in the serum of ducks exposed to low ambient temperature at $2(p<0.01), 7(p<0.05), 14(p<0.01)$, and $21(p<0.01) \mathrm{d}$. There were no significant differences in blood biochemistry (total cholesterol, glucose, calcium, AST, and ALT; Table 4) between groups. However, triglycerides increased (linear and quadratic, $p<0.05$ ) with increasing inclusion level of energy in duck diets $(258.0,280.6,273.3,304.3$, and $396.1 \mathrm{mg} / \mathrm{dL}$ for 2,950 to $3,150 \mathrm{kcal} \mathrm{ME} / \mathrm{kg}$, respectively). Compared to the $2,950 \mathrm{kcal}$
$\mathrm{ME} / \mathrm{kg}$ treatment, triglycerides increased by $8.8 \%, 5.9 \%, 17.9 \%$, and $53.5 \%$, respectively, for the 3,000-3,150 kcal AME $/ \mathrm{kg}$ groups. There were no significant changes in villus height or crypt depth in the jejunum at 7,14, or $21 \mathrm{~d}$ in the intestines of ducks exposed to low ambient temperature (Table 5).

\section{Discussion}

Results of feed intake are in agreement with [5] who have reported that low ambient temperatures $\left(10.47 \pm 3.3^{\circ} \mathrm{C}\right)$ cause an increase in feed intake. Since low ambient temperature stress causes an increase in feed intake it is difficult to further increase feed intake at the dietary energy level as an index to improve the positive effect of cold stress. Therefore, under unfavorable causes such as paying

Table 4. Blood biochemistry of exposed low ambient temperature as affected by different AME concentration in diets

\begin{tabular}{|c|c|c|c|c|c|c|c|c|}
\hline \multirow{2}{*}{ Items } & \multicolumn{5}{|c|}{ Dietary ME concentrations (kcal/kg) } & \multirow{2}{*}{ SEM $^{1)}$} & \multicolumn{2}{|c|}{$p$-value } \\
\hline & 2,950 & 3,000 & 3,050 & 3,100 & 3,150 & & Linear & Quadratic \\
\hline Total cholesterol (mg/dL) & 208.1 & 205.9 & 208.3 & 204.9 & 209.9 & 8.86 & 0.182 & 0.192 \\
\hline Triglyceride (mg/dL) & 258.0 & 280.6 & 273.3 & 304.3 & 396.1 & 18.27 & $<0.010$ & 0.033 \\
\hline Glucose (mg/dL) & 185.2 & 174.5 & 197.0 & 218.5 & 191.0 & 8.22 & 0.122 & 0.288 \\
\hline Asparate aminotransferase (U/L) & 13.12 & 14.63 & 15.77 & 14.64 & 12.06 & 1.79 & 0.388 & 0.251 \\
\hline Alanine transaminase $(\mathrm{U} / \mathrm{L})$ & 35.17 & 37.46 & 29.72 & 39.99 & 34.78 & 4.71 & 0.916 & 0.873 \\
\hline Calcium (mg/dL) & 12.57 & 11.48 & 11.47 & 12.21 & 12.22 & 0.15 & 0.955 & 0.207 \\
\hline
\end{tabular}

Data are least squares means of 8 observations per treatment.

${ }^{1)}$ Pooled error of mean.

ME, metabolizable energy. 
Table 5. Intestinal morphology of exposed low ambient temperature as affected by different AME concentration in diets

\begin{tabular}{|c|c|c|c|c|c|c|c|c|}
\hline \multirow{2}{*}{ Items } & \multicolumn{5}{|c|}{ Dietary AME concentrations (kcal/kg) } & \multirow{2}{*}{ SEM ${ }^{1)}$} & \multicolumn{2}{|c|}{$p$-value } \\
\hline & 2,950 & 3,000 & 3,050 & 3,100 & 3,150 & & Linear & Quadratic \\
\hline \multicolumn{9}{|l|}{7 day } \\
\hline Villus height $(\mu \mathrm{m})$ & 653.7 & 634.5 & 645.8 & 646.4 & 710.6 & 49.48 & 0.492 & 0.453 \\
\hline Crypth depth $(\mu \mathrm{m})$ & 121.5 & 139.4 & 128.7 & 171.9 & 158.9 & 17.97 & 0.258 & 0.892 \\
\hline \multicolumn{9}{|l|}{14 day } \\
\hline Villus height $(\mu \mathrm{m})$ & 669.9 & 713.7 & 773.5 & 785.8 & 697.1 & 47.19 & 0.452 & 0.092 \\
\hline Crypth depth $(\mu \mathrm{m})$ & 143.5 & 137.5 & 120.1 & 121.2 & 138.1 & 12.33 & 0.123 & 0.841 \\
\hline \multicolumn{9}{|l|}{21 day } \\
\hline Villus height $(\mu \mathrm{m})$ & 836.8 & 868.6 & 808.9 & 963.4 & 935.2 & 71.28 & 0.232 & 0.761 \\
\hline Crypth depth $(\mu \mathrm{m})$ & 157.6 & 146.1 & 170.8 & 127.8 & 130.5 & 13.51 & 0.121 & 0.512 \\
\hline
\end{tabular}

Data are least squares means of 8 observations per treatment.

${ }^{1)}$ Pooled error of mean.

ME, metabolizable energy.

excessive energy demand at low temperature. According to reports, weight gain is positively correlated with feed intake. Birds consumed more feed, resulting in higher weight gain and proved our observation [8]. Dietary fat supplementation has been shown to improve feed conversion and decrease feed intake of broiler chickens [18-23]. Doizer et al. [22] evaluated responses of broilers fed diets varying in $\mathrm{AME}_{\mathrm{n}}$ from 3,175 to $3,310 \mathrm{kcal} / \mathrm{kg}$ during 30 to $59 \mathrm{~d}$ of age. It was determined that feed intake and feed conversion decreased linearly with $\mathrm{AME}_{\mathrm{n}}$ content in these diets. Also, previous research has established that feeding broilers diets containing $\mathrm{AME}_{\mathrm{n}}$ concentrations improved body weight [19-21,24]. These results agree with the results of Jensen et al. [25] who found an "extra caloric" effect for supplemented fat and suggested that wide caloric/protein ratios in poultry rations with additional fat can be used for maximum gain and feed efficiency. In concordance with other studies, in this study there were no significant differences in energy intake between the groups due to the decrease in feed intake with increasing dietary energy.

The $\mathrm{H} / \mathrm{L}$ ratio has proved to be a valuable measurement in stress-related research in poultry [26-28], and it has been shown to be highly heritable [29] and a reliable index for determining stress in these birds [30]. Physiological and physical stressors increase the H/L ratio [31]. Hangalapura et al. [32] found a significant enhancing effect of low ambient temperature on in vitro lymphocyte proliferation. With respect to the $\mathrm{H} / \mathrm{L}$ ratio, Hester et al. [33] also found that caged white leghorn hens exposed to a cold environment had a higher $\mathrm{H} / \mathrm{L}$ ratio than those of the control hens. In relation to plasma corticosterone concentration (another stress indicator), Buckland et al. [34] reported that the application of cold stress resulted in significant increases in plasma corticosterone levels in chicks. Thus, blood parameters are good indicators of the physiological, pathological, and nutritional status of a bird, and changes in hematological parameters have the potential of being used to elucidate the impact of nutritional factors and additives supplied in diet on any living creature. Leukocyte counts also have been used as a measure of immune function in birds [35]. Many factors such as exposure to various microbes and chemicals substances can cause change in leukocytes [35]. The lack of adequate data on the influence of dietary level of energy of ducks exposed to low ambient temperature in altering blood parameters in poultry requires further research. Triglycerides are hydrophobic and can be stored in a very compact form [36]. In poultry, triglyceride are derived from exogenous de novo sources or from the conversion of glucose to fat. Therefore, triglyceride content is strongly influenced by the proportion of carbohydrates in the diet and the species' response to lipolytic hormones, which affects the balance between lipolysis and esterification [37]. The marked increase in the percentage of triglycerides and phospholipids in the serum of ducks fed diets with an increasing amount of energy is thus likely caused by the high-energy diets suggesting a direct relationship between triglycerides and dietary energy content.

Crypth depth and villus height: crypth depth ratio was not influenced by increasing level of dietary energy. Development of intestinal morphology could reflect the health status of the GI tract of an animal. New epithelial cells are produced in the intestinal mucosal crypts and migrate along with the villus to the top [38]. As the intestines are a major site of enzymatic digestion and absorption of nutrients, absorption efficiency, and therefore FCR, is highly dependent on intestinal morphology [39]. The deeper the crypts, the faster the tissue rotates and the more likely the villus is renewed. This suggests that the host intestinal response mechanism attempts to compensate for the normal loss or atrophy of the villi due to inflammation by pathogens and their toxins [40]. Previous research have shown that the intestinal morphology, specifically 
structures such as villus, crypts and the thickness of mucosa, were altered by the composition of diet [41]. The increase in villus height and crypt depth is associated with healthy turnover of epithelial cell and active cell mitosis [42].

The results and ongoing discussion suggested that dietary increasing level of energy supplementation alleviates the adverse effect of cold induced stress and improved the production performance in pekin ducks. Additionally, 3,150 kcal/ $\mathrm{kg}$ dietary energy had been revealed more beneficial and could be practiced as protective management for the pekin ducks reared under low ambient temperature.

\section{Competing interests}

No potential conflict of interest relevant to this article was reported.

\section{Funding sources}

This work was supported by the research grant from the Rural Development Administration, Korea, PJ01008802, and Rural Development Administration, Korea and this study was supported by 2019 the RDA Fellowship Program of, National Institute of Animal Science, Rural Development Administration, Korea.

\section{Acknowledgements}

Not applicable.

\section{Availability of data and material}

Upon reasonable request, the datasets of this study can be available from the corresponding author.

\section{Authors' contributions}

Conceptualization: $\mathrm{Kim} \mathrm{CH}$.

Data Curation: Kim CH, Kang HK.

Formal analysis: $\mathrm{Kim} \mathrm{CH}$.

Methodology: Kim CH, Kang HK.

Validation: Kang HK.

Investigation: Kim CH.

Writing - original draft: Kim CH, Kang HK, Kim HS.

Writing - review \& editing: Kim CH, Kang HK, Kim HS.

\section{Ethics approval and consent to participate}

This article does not require IRB/IACUC approval because there no experiments directly conducted to human and animals.

\section{ORCID}

Chan Ho Kim https://orcid.org/0000-0003-2121-5249

Hwan Ku Kang Hyun Soo Kim https://orcid.org/0000-0002-4286-3141

https://orcid.org/0000-0001-8887-1318

\section{References}

1. Dietert RR, Golemboski KA, Austic RE. Environment-immune interactions. Poult Sci.1994;73:1062-76.

2. Hernawan E, Wahyuni S, Suprapti H. The levels of blood glucose, triglyceride, final body weight and abdominal fat percentage of broiler under sex-separated and straight run rearing system. Lucrari Stiintifice-Seria Zootehnie. 2012;57:28-33.

3. Zhang ZW, Lv ZH, Li JL, Li S, Xu SW, Wang XL. Effects of cold stress on nitric oxide in duodenum of chicks. Poult Sci. 2011;90:1555-61.

4. Dhanalakshmi S, Devi RS, Srikumar R, Manikandan S, Thangaraj R. Protective effect of triphala on cold stress-induced behavioral and biochemical abnormalities in rats.J Pharm Soc Jpn. 2007;127:1863-7.

5. Sahin K, Kucuk O, Sahin N. Effects of dietary chromium picolinate supplementation on performance and plasma concentrations of insulin and corticosterone in laying hens under low ambient temperature. J Anim Physiol Anim Nutr. 2001;85:142-7.

6. Spinu M, Degen AA. Effect of cold stress on performance and immune responses of Bedouin and White Leghorn hens. Br Poult Sci. 1993;34:177-85.

7. Shit N, Singh RP, Sastry KV, Agarwal R, Singh R, Pandey NK, et al. Effect of dietary L-ascorbic acid (L-AA) on production performance, egg quality traits and fertility in Japanese Quail (Coturnix japonica) at low ambient temperature. Asian-Australas J Anim Sci. 2012;25:1009-14.

8. Donkoh A. Ambient temperature: a factor affecting performance and physiological response of broiler chickens. Int J Biometeorol. 1989;33:259-65.

9. Siegel HS. Stress, strains and resistance. Br Poult Sci. 1995;36:322.

10. Mowat DN. Organic chromium in animal nutrition. Guelph: Chromium Books; 1997.

11. Noblet J, Fortune H, Shi XS, Dubois S. Prediction of net energy value of feeds for growing pigs.J Anim Sci. 1994;72:344-54.

12. Cole DJA, Duckworth JE, Holmes W. Factors affecting voluntary feed intake in pigs: I. the effect of digestible energy content of the diet on the intake of castrated male pigs housed in holding pens and in metabolism crates. Anim Sci. 1967;9:141-8.

13. Chadd SA, Cole DJA. The performance response of growing and finishing pigs fed differing proportions oat feed as a dietary fibre source. In: Proceedings of EAAP Annual Meeting; 1999; Zurich.

14. Smith JW, Tokach MD, O'Quinn PR, Nelssen JL, Goodband $\mathrm{RD}$. Effects of dietary energy density and lysine:calorie ratio 
on growth performance and carcass characteristics of growing-finishing pigs.J Anim Sci. 1999;77:3007-15.

15. NRC [National Research Council]. Nutrient requirements of poultry. 9th ed. Washington, DC: National Academy Press; 1994.

16. AOAC. Official methods of analysis. 18th ed. Arlington, VA: Association of Official Analytical Chemists; 2007.

17. Li P, Piao X, Ru Y, Han X, Xue L, Zhang H. Effects of adding essential oil to the diet of weaned pigs on performance, nutrient utilization, immune response and intestinal health. Asian-Australas J Anim Sci. 2012;25:1617-26.

18. Leeson S, Caston L, Summers JD. Broiler response to diet energy. Poult Sci. 1996;75:529-35.

19. Cheng TK, Hamre ML, Coon CN. Effect of environmental temperature, dietary protein, and energy levels on broiler performance.J Appl Poult Res. 1997;6:1-17.

20. Hidalgo MA, Dozier WA, Davis AJ, Gordon RW. Live performance and meat yield responses of broilers to progressive concentrations of dietary energy maintained at a constant metabolizable energy-to-crude protein ratio.J Appl Poult Res. 2004;13:319-27.

21. Doizer WA, Price CJ, Kidd MT, Corzo A, Anderson J, Branton SL. Growth performance, meat yield, and economic responses of broilers fed diets varying in metabolizable energy from thirty to fifty-nine days of age. J Appl Poult Res. 2006;15:367-82.

22. Doizer WA, Corzo A, Kidd MT, Branton SL. Dietary apparent metabolizable energy and amino acid density effects on growth and carcass traits of heavy broilers. J Appl Poult Res. 2007;16:192-205.

23. Jackson S, Summers JD, Leeson S. Effect of dietary protein and energy on broiler performance and production costs. Poult Sci. 1982;61:2232-40.

24. Jensen LS, Schumaier GW, Latshaw JD. "Extra caloric" effect of dietary fat for developing turkeys as influenced by calorie-protein ratio. Poult Sci. 1970;49:1679-704.

25. Huff GR, Huff WE, Balog JM, Rath NC, Anthony NB, Nestor KE. Stress response differences and disease susceptibility reflected by heterophil to lymphocyte ratio in turkeys selected for increased body weight. Poult Sci. 2005;84:709-17.

26. Post J, Rebel JM, ter Huurne AA. Automated blood cell count: a sensitive and reliable method to study corticosterone-related stress in broilers. Poult Sci. 2003;82:591-5.

27. Lentfer TL, Pendl H, Gebhardt-Henrich SG, Frohlich EK, Von Borell E. H/L ratio as a measurement of stress in laying hens - methodology and reliability. Br Poult Sci. 2015;56: 157-
63.

28. Al-Murrani WK, Kassab A, Al-Sam HZ, Al-Athari AM. Heterophil/lymphocyte ratio as a selection criterion for heat resistance in domestic fowl. Br Poult Sci. 1997;38:159-63.

29. Gross WB, Siegel HS. Evaluation of the heterophil/lymphocyte ratio as a measure of stress in chickens. Avian Dis. 1983;27:972-9.

30. Maxwell MH, Robertson GW. The avian heterophil leukocyte: a review. Worlds Poult Sci J. 1998;54:155-78.

31. Hangalapura BN, Nieuwland MG, de Vries Reilingh G, van den Brand H, Kemp B, Parmentier HK. Durations of cold stress modulates overall immunity of chicken lines divergently selected for antibody responses. Poult Sci. 2004;83:765-75.

32. Hester PY, Muir WM, Craig JV, Albright JL. Group selection for adaptation to multiple-hen cages: Hematology and adrenal function. Poult Sci. 1996;75:1295-307.

33. Buckland RB, Blagrave K, Lague PC. Competitive protein-binding assay for corticoids in the peripheral plasma of the immature chicken. Poult Sci. 1974;53:241-5.

34. Johnson TS, Zuk M. Parasites, morphology, and blood characters in male red jungle fowl during development. Condor. 1998;100:749-52.

35. Lucas AM, Jamroz C. Atlas of avian hematology. Agriculture monograph no. 25. Wahsington, DC: USDA; 1961.

36. Klasing KC. Comparative avian nutrition. Wallingford: $\mathrm{Cab}$ International, 1998.

37. Harper HA, Rodwell VW, Mayes PA. Review of biochemistry. 19th ed. Los Altos, CA: Lange Medical Publications; 1987.

38. Schat K, Myers TJ. Avian intestinal immunity. Crt Rev Poult Biol. 1991;3:19-34.

39. Soltan MA. Influence of dietary glutamine supplementation on growth performance, small intestinal morphology, immune response and some blood parameters of broiler chickens. Int J Poult Sci. 2009;8:60-8.

40. Gao J, Zhang HJ, Yu SH, Wu SG, Yoon I, Quigley J, et al. Effects of yeast culture in broiler diets on performance and immunomodulatory functions. Poult Sci. 2008;87:1377-84.

41. Nain S, Renema RA, Zuidhof MJ, Korver DR. Effect of metabolic efficiency and intestinal morphology on variability in n-3 polyunsaturated fatty acid enrichment of eggs. Poult Sci. 2012;91:888-98.

42. Fan YK, Croom J, Christensen VL, Black BL, Bird AR, Daniel LR, et al. Jejunal glucose uptake and oxygen consumption in turkey poults selected for rapid growth. Poult Sci. 1997;76:1738-45. 